\title{
Hydrazinolysis study of phthalimido- and phthalisoimido-penicillin amide derivatives
}

\author{
Helena Cerića and Marija Šindler-Kulyk ${ }^{\mathrm{b}}$ * \\ ${ }^{a}$ PLIVA Croatia Ltd., Research and Development of API, Chemistry, Prilaz baruna Filipovića \\ 25, 10000 Zagreb, Croatia \\ ${ }^{b}$ Department of Organic Chemistry, Faculty of Chemical Engineering and Technology, \\ University of Zagreb, Marulićev trg 19, 10000 Zagreb, Croatia \\ E-mail: msindler@pierre.fkit.hr
}

\begin{abstract}
New phthalimido-penicillin amide (6-PhtPABn) and phthalisoimido-penicillin amide (6isoPhtPABn) were prepared and the susceptibility of their different carbonyl functions toward hydrazine derivatives investigated in order to establish the feasibility of dephthaloylation within penicillin class compounds. Hydrazinolysis of phthalimido-penicillin amide (6-PhtPABn) resulted in dephthaloylation and $\beta$-lactam ring opening into thiazolidine derivatives, while in the case of phthalisoimido-penicillin amide (6-isoPhtPABn), the desired amino-penicillin amide (6APABn) was isolated in low yield.
\end{abstract}

Keywords: $\beta$-Lactam, dephthaloylation, hydrazinolysis, penicillin, phthaloyl-protection, thiazolidine

\section{Introduction}

$\beta$-Lactam antibiotics have been successfully used in the treatment of infectious diseases for many years. ${ }^{1}$ Despite the large number of $\beta$-lactams that have already been synthesized and tested, there is still a need for new compounds of this kind, ${ }^{2}$ due to the increasing resistance of bacterial strains to certain types of anti-infectives. ${ }^{3}$

It has been recognized that phthalimido-containing $\beta$-lactams are more stable to a wide variety of reaction conditions than the corresponding amido derivatives, making feasible many chemical reactions that were otherwise impracticable. ${ }^{4}$ However, the obvious advantages of the phthaloyl protective group have been overshadowed by the lack of a selective removal method in the case of cephalosporins and penicillins. On these substrates, the general Ing-Manske method ${ }^{5}$ for dephthaloylation with hydrazine derivatives can lead to possible $\beta$-lactam ring opening. 
Several examples of successful dephthaloylation with hydrazine derivatives have been reported on monocyclic $\beta$-lactams, ${ }^{6}$ but only a few examples on bicyclic derivatives like cephalosporins, ${ }^{7}$ carbacephems ${ }^{8}$ and isocephems ${ }^{9}$ as well as tricyclic $\beta$-lactams. ${ }^{10}$ It has been found that in the case of penicillin-esters, ${ }^{11}$ phthalimido group had to be converted to phthalisoimido group prior to hydrazinolysis in order to avoid $\beta$-lactam ring opening.

As a part of our work ${ }^{12}$ on preparation of new $\beta$-lactam derivatives with potential biological activity, new phthalimido-penicillin amide (6-PhtPABn) and phthalisoimido-penicillin amide (6isoPhtPABn) were prepared and feasibility of their dephthaloylation with hydrazines studied.

\section{Results and Discussion}

Synthesis of phthalimido-penicillin amide 1 (6-PhtPABn) was carried out by amidation of previously prepared 6-phthalimidopenicillanic acid (6-PhtPA $)^{13}$ with benzylamine $(91 \%$ yield, Scheme 1). Amidation was carried out by a method commonly applied in organic synthesis and used in penicillin chemistry ${ }^{14}$. 6-PhtPABn (1) was transformed to phthalisoimido-penicillin amide 3 (6-isoPhtPABn) via phthalic acid 2 by a modified procedure described on related phthalimido-penicillin esters. ${ }^{11}$ The first step in the synthesis is the hydrolysis of compound $\mathbf{1}$. The reaction is carried out by slow addition of aqueous sodium sulfide to THF solution of compound $\mathbf{1}$, followed by neutralization and evaporation of THF. It is important to maintain low reaction temperature and to adjust the $\mathrm{pH}$ of the solution prior to evaporation in order to minimize the $\beta$-lactam ring opening. Pure compound 2 can be obtained as a precipitate (46\%) by acidifying water/acetonitrile mixture under the $\mathrm{pH}$ control.
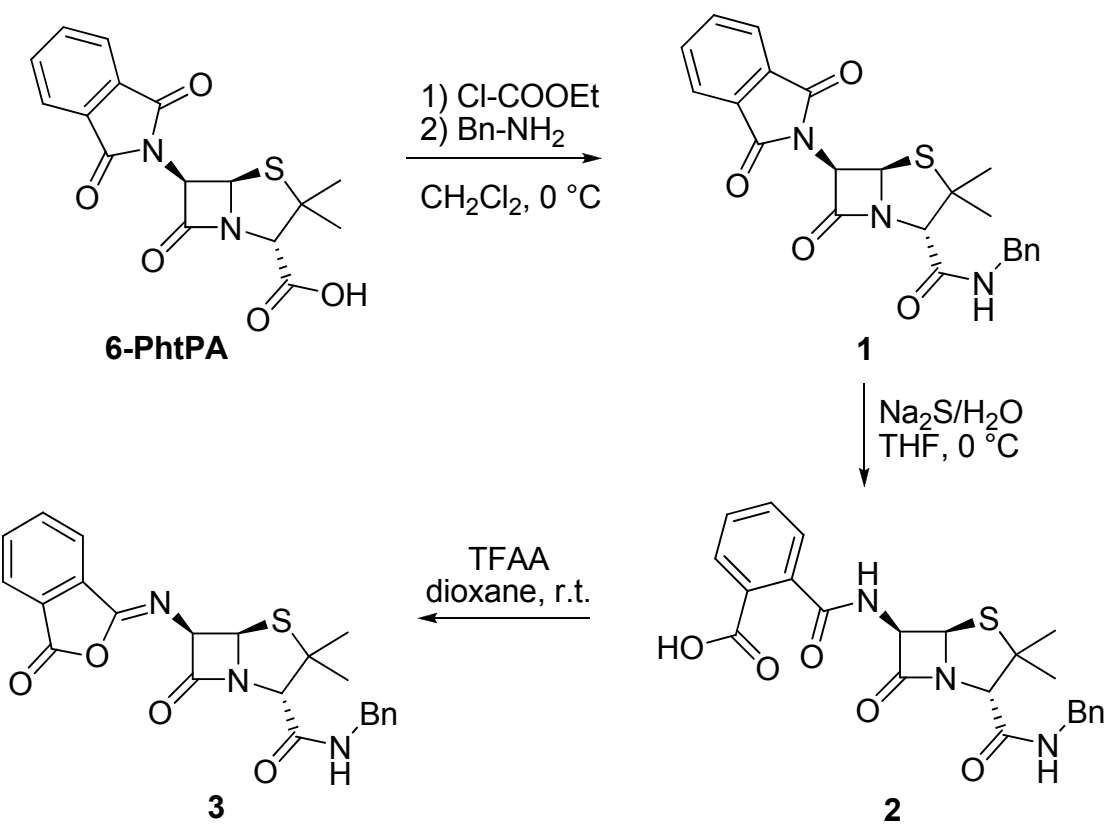

\section{Scheme 1}


One of the by-products that remained in mother liquor was isolated (3\%) and its structure assigned to thiazolidine compound 4 (Scheme 2), confirming $\beta$-lactam ring opening. ${ }^{15}$

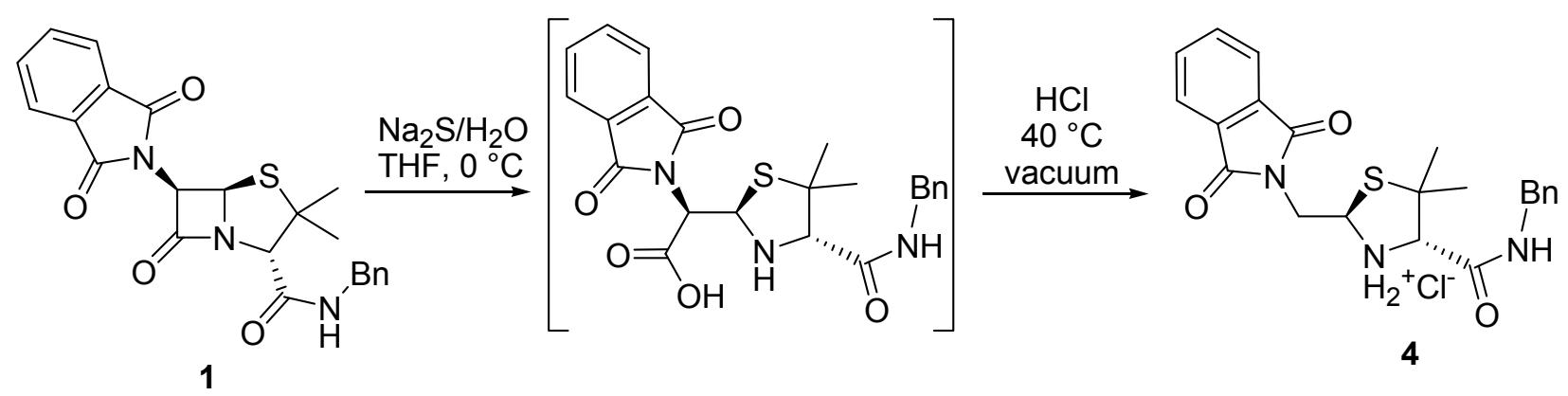

\section{Scheme 2}

The target compound $\mathbf{3}$ was prepared by treatment of compound $\mathbf{2}$ in dry dioxan with the excess of trifluoroacetic acid anhydride (TFAA) and isolated by precipitation with water in very good yield (95\%). The compound $\mathbf{3}$ has a tendency to convert back into compound $\mathbf{2}$ and therefore it should be prepared right before the next step of hydrazinolysis.

Structures of new compounds 1-4 were determined by spectroscopic data. ${ }^{1} \mathrm{H}$ NMR of compound 1 showed the retained Z-configuration of $\beta$-lactam ring: $\mathrm{C}_{5}-\mathrm{H}$ and $\mathrm{C}_{6}-\mathrm{H}$ gave corresponding doublets at 5.57 and $5.73 \mathrm{ppm}$, respectively, with coupling constant of $4.0 \mathrm{~Hz}$. The $\mathrm{CONH}$ and its neighboring $\mathrm{CH}_{2}$ group can be found as doublets at 8.78 and 4.33 ppm, respectively, with coupling constant of $5.9 \mathrm{~Hz}$. Signals of phenyl and phthalimido aromatic hydrogens appeared as multiplets at 7.26-7.36 and 7.89-7.94 ppm, respectively. The ring opening of phthalimido moiety in structure 2 was evident from the splitting pattern of $\mathrm{C}_{6}$ - $\mathrm{H} \beta$-lactam proton. It is additionally coupled with the new $\mathrm{CONH}$ proton and appears as a doublet of doublets at $5.55 \mathrm{ppm}$. New signals of $\mathrm{CONH}$ at 9.27 and $\mathrm{COOH}$ at $12.94 \mathrm{ppm}$ disappear after a $\mathrm{D}_{2} \mathrm{O}$ shake. ${ }^{1} \mathrm{H}$ NMR of compound 3 had no signals that could be attributed to $\mathrm{COOH}$ or $\mathrm{CONH}$ groups of phthalamic acid $\mathbf{2}$, in accordance with the closed structure of phthalisoimide ring. The $\beta$-lactam protons appeared as two doublets with coupling constant corresponding to Zconfiguration. The thiazolidine compound 4, formed as a byproduct during the preparation of compound 2, showed no signals characteristic for $\beta$-lactam hydrogens in ${ }^{1} \mathrm{H}$ NMR. Protonated thiazolidine $\mathrm{NH}$ was found at $3.35 \mathrm{ppm}$ as a broad singlet. Geminal protons of new methylene group appeared as two doublet of doublets at 3.47 and $3.75 \mathrm{ppm}$ with the geminal coupling constant of $13.9 \mathrm{~Hz}$, each split with the neighboring chiral center with different coupling constants of 5.3 and $9.8 \mathrm{~Hz}$.

The obtained phthalisoimido-penicillin amide 3 (6-isoPhtPABn) was further subjected to hydrazinolysis with methyl hydrazine (Scheme 3), according to the procedure described for penicillin esters. ${ }^{11}$ The hydrazinolysis requires very low temperature and even when it was carried out at $0{ }^{\circ} \mathrm{C}$ no penicillin compound $\mathbf{5}$ (6-APABn) could be isolated due to $\beta$-lactam ring opening. When the reaction was carried out at $-75^{\circ} \mathrm{C}$ in $\mathrm{DCM}$, instead of THF as described in 
the literature, the hydrazide compound $\mathbf{6}$ precipitated after the reaction mixture has reached the RT, thus avoiding the evaporation step and chloroform work up. From the mother liquor the free amino-penicillin amide $\mathbf{5}$ (6-APABn), presumably formed via $\mathbf{7 a}$ and/or $\mathbf{7 b}$ intermediate, was isolated by acid-base extractions in $12 \%$ yield. ${ }^{1} \mathrm{H}$ and ${ }^{13} \mathrm{C}$ NMR of compound 5 showed no signals that could be attributed to phthaloyl moiety, confirming successful dephthaloylation and formation of new $\mathrm{NH}_{2}$ group, found as a broad singlet at $2.16 \mathrm{ppm}$.

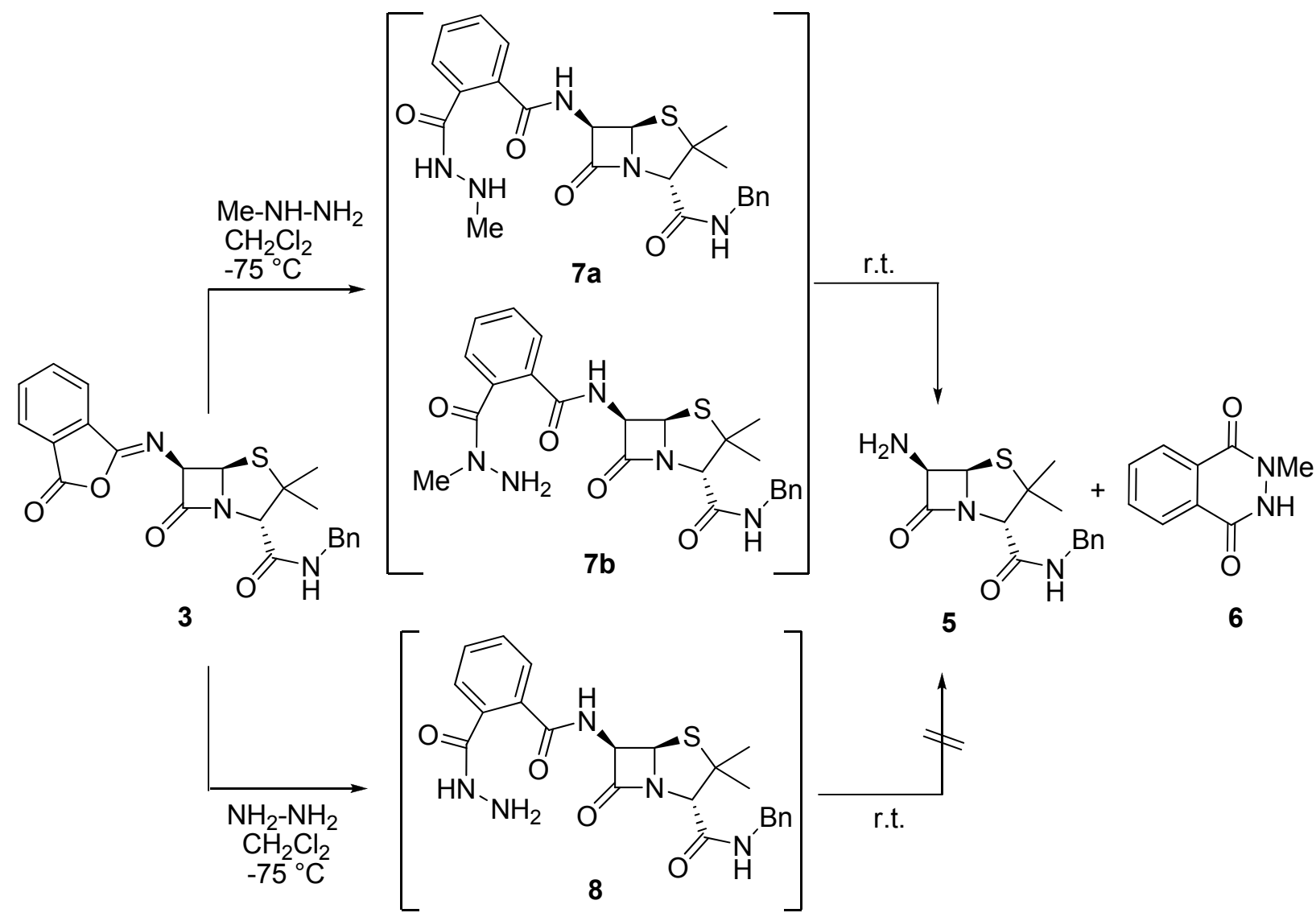

\section{Scheme 3}

When the hydrazinolysis was carried out under the same conditions but using hydrazine instead of methyl hydrazine, no product 5 was isolated. Monitoring the reaction by HPLC/MS corresponding intermediate hydrazino-adduct 8 was found (Scheme 3). We assume that hydrazine and methylhydrazine nitrogens are all basic enough for the first nucleophilic attack on ester-carbonyl group and formation of intermediates $\mathbf{7 a}, \mathbf{7 b}$ and $\mathbf{8}$. However, the second intramolecular nucleophilic attack on amido-carbonyl group and the separation of phthalhydrazide in the case of intermediate $\mathbf{8}$ did not proceed under the same conditions. Based on this, it might be that in the reaction with methylhydrazine only intermediate $7 \mathbf{a}$ closes to hydrazide 6 giving the free amino-compound 5 that could contribute to the low yield of compound 5. The other side-reaction, adding further to the low yield of compound $\mathbf{5}$ is the 
competitive nucleophilic attack of hydrazine on $\beta$-lactam-carbonyl resulting in $\beta$-lactam ring opening and formation of thiazolidine derivatives.

As the overall yield on compound 5 obtained by dephthaloylation of 6-PhtPABn (1) via 6isoPhtPABn (3) was very low (5\%), the possibility to find the reaction conditions for direct dephthaloylation of 1 was explored. In the reaction of 6-PhtPABn (1), regardless of the reaction conditions and hydrazine derivative used, no compound $\mathbf{5}$ was found. Monitoring the reaction by HPLC/MS one-hydrazino-adducts $\mathbf{8}$ and $\mathbf{9}$ and two-hydrazino-adduct $\mathbf{1 0}$ were detected immediately after the first addition of hydrazine (Scheme 4). Intermediate 8, presumably also formed from 3 (Scheme 3), could be explained by initial nucleophilic attack on phthalimido moiety of compound 1. Compound 9 could be formed if the attack is on $\beta$-lactam ring. Both, 8 and $\mathbf{9}$, could undergo an additional hydrazine attack to give compound $\mathbf{1 0 .}$

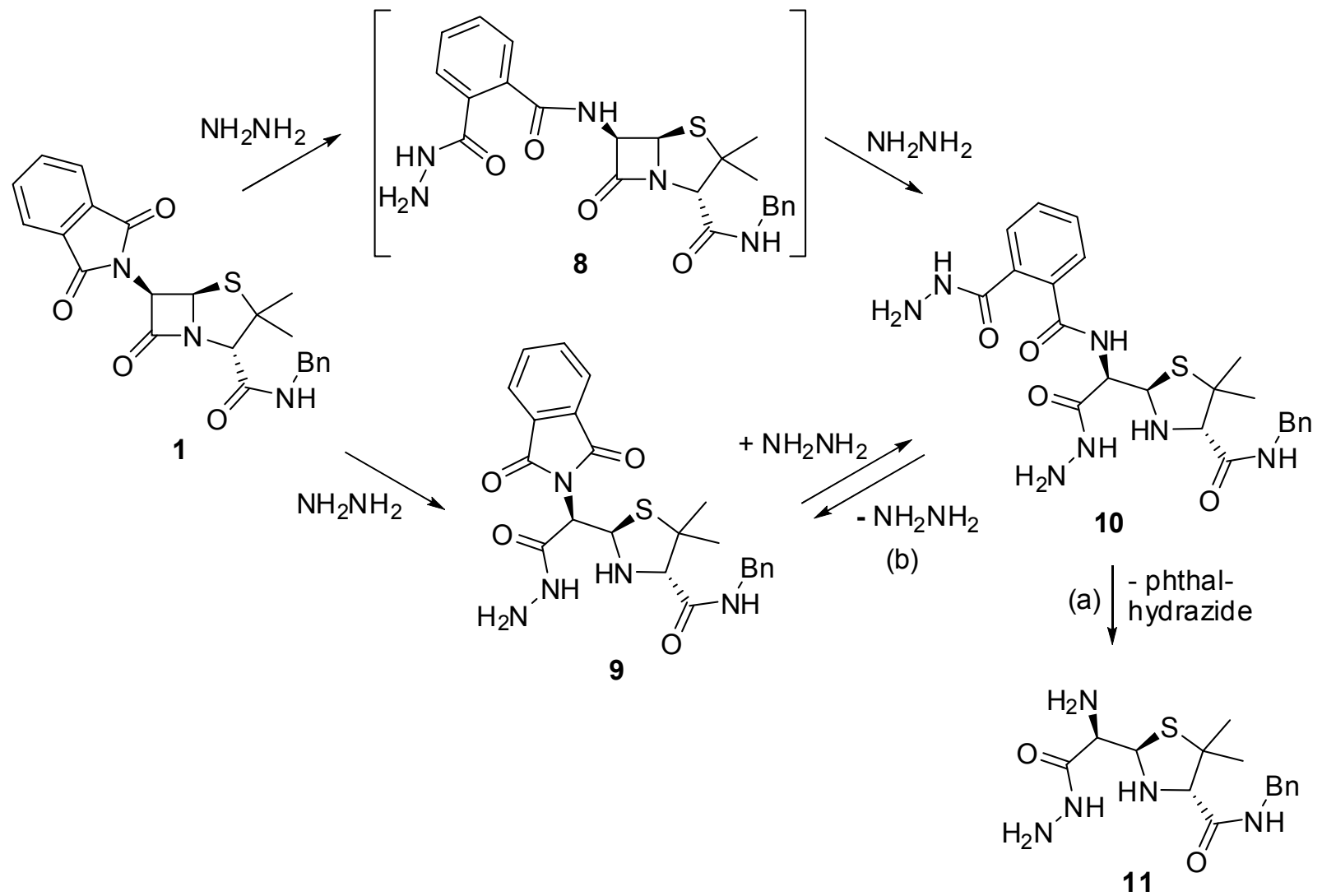

\section{Scheme 4}

The pure compound 10 was isolated (24\%) from the reaction of 1 in toluene with the excess of hydrazine. On heating in alcoholic solution, the obtained compound $\mathbf{1 0}$ was found to transform by dephthaloylation (a) into compound 11 (36\%) and by phthalimido ring closure (b) into compound 9 (45\%) (Scheme 4$)$. 
The structures of obtained new thiazolidine derivatives $\mathbf{9 , 1 0}$ and $\mathbf{1 1}$ were determined by spectroscopic data. The structure of one-hydrazino-adduct 9 was based on new NH signal pattern in ${ }^{1} \mathrm{H}$ NMR that could only be attributed to thiazolidine amine, as opposed to one-hydrazinoadduct 8. Namely, thiazolidine $\mathrm{NH}$ of compound $\mathbf{9}$ appears as a characteristic doublet of doublets at 3.84 ppm split by a neighboring thiazolidine $\mathrm{C}_{2}-\mathrm{H}$ and $\mathrm{C}_{4}-\mathrm{H}$ groups with coupling constants of $J=8.1$ and $13.3 \mathrm{~Hz}$, respectively. ${ }^{1} \mathrm{H}$ and ${ }^{13} \mathrm{C}$ NMR of compound $\mathbf{1 0}$ showed that both phthalimido and $\beta$-lactam rings were opened: new thiazolidine $\mathrm{NH}$ appeared as a corresponding doublet of doublets at $3.91 \mathrm{ppm}$ while $\mathrm{CONH}$ from phthalimido ring opening appeared as a doublet at $8.38 \mathrm{ppm}$. Hydrazide $\mathrm{NH}$ groups were found as singlets at 9.21 and $9.59 \mathrm{ppm}$. All of the described $\mathrm{NH}$ signals disappear after a $\mathrm{D}_{2} \mathrm{O}$ shake. ${ }^{13} \mathrm{C}$ NMR of compound $\mathbf{1 0}$ also showed four different carbonyl functions. ${ }^{1} \mathrm{H}$ and ${ }^{13} \mathrm{C}$ NMR spectra of compound 11 were in accordance with open $\beta$-lactam ring and showed no signals corresponding to phthaloyl moiety, suggesting successful dephthaloylation and formation of free $\mathrm{NH}_{2}$ group, found at $2.00 \mathrm{ppm}$ as a broad singlet.

\section{Conclusions}

The dephthaloylation of phthalimido-penicillin amide $\mathbf{1}$ resulted in $\beta$-lactam ring opening and formation of new thiazolidine compounds. The nucleophilic attack of hydrazine on phthalimido moiety and $\beta$-lactam ring in penicillin-amide system is a competitive process. The aptitude to $\beta$ lactam ring opening is driven by the formation of stable thiazolidine compounds.

By transforming phthalimido into more reactive phthalisoimido group it was possible to partially preserve $\beta$-lactam ring in compound $\mathbf{3}$ from hydrazinolysis and to isolate the desired amino-penicillin amide $\mathbf{5}$ in low yield.

\section{Experimental Section}

General Procedures. All melting points were determined on Büchi B-540 apparatus in capillary tubes and are uncorrected. IR spectra were recorded on $\mathrm{KBr}$ discs on a Perkin Elmer SpectrumGX FT-IR spectrophotometer with a resolution of $4 \mathrm{~cm}^{-1} .{ }^{1} \mathrm{H}$ and ${ }^{13} \mathrm{C}$ NMR spectra were recorded on Bruker Avance 300 and Bruker Avance 600 spectrometers with TMS as an internal standard. Column chromatography was carried out on silica gel MerckKieselgel 60, 0.04-0.063 mm. HPLC was performed on Agilent 1100 instrument with DAD detector and ESI LC/MSD trap on column Phenomenex Gemini C18 with gradient elution (acetonitrile: ammonium acetate buffer, pH 7.4=20:80 to 90:10). High Resolution Mass Spectra (HRMS) were recorded on Micromass Q-Tof micro ${ }^{\mathrm{TM}}$ instrument equipped with the lock-spray (Waters Corporation, Manchester, UK). Elemental analysis was carried out on Perkin Elmer 2400 Series II CHNS/O analyzer. Water content was determined by coulometric Karl Fischer titration on 
Metrohm 831 KF Coulometer. Chemicals 6-APA, ethyl chloroformate and benzylamine, purum were purchased from Fluka. Hydrazine 1.0 M in THF, hydrazine monohydrate (98\%) and methylhydrazine (98\%) were purchased from Aldrich.

(2S,5R,6R)-6-(1,3-Dioxoisoindolin-2-yl)-3,3-dimethyl-7-oxo-4-thia-1-azabicyclo-[3.2.0] heptane-2-carboxylic acid (6-PhtPA). Mp 176-179 ${ }^{\circ} \mathrm{C}$; lit. ${ }^{13} \mathrm{mp} 178-180{ }^{\circ} \mathrm{C}$.

\section{2-((2S,5R,6R)-2-((Benzylaminooxy)carbonyl)-3,3-dimethyl-7-oxo-4-thia-1-aza-bicyclo-}

[3.2.0]heptane-6-yl)isoindoline-1,3-dione (1). 6-PhtPA (10.0 g, $28.9 \mathrm{mmol})$ was dissolved in DCM $(300 \mathrm{~mL})$ by addition of triethylamine $(4.0 \mathrm{~mL}, 28.9 \mathrm{mmol})$. The solution was cooled to 0 ${ }^{\circ} \mathrm{C}$ and ethyl chloroformate $(2.62 \mathrm{~mL}, 32.4 \mathrm{mmol})$ in DCM $(150 \mathrm{~mL})$ was added. The reaction mixture was stirred for $1 / 2 \mathrm{~h}$ at $0{ }^{\circ} \mathrm{C}$. Benzylamine $(3.26 \mathrm{~mL}, 29.9 \mathrm{mmol})$ in DCM $(40 \mathrm{~mL})$ was added drop wise to the reaction mixture during $1 / 2 \mathrm{~h}$ and stirring was continued for $2 \mathrm{~h}$ at $0{ }^{\circ} \mathrm{C}$. Water $(500 \mathrm{~mL})$ was added and the layers were separated. The organic layer was washed with water $(500 \mathrm{~mL})$ and dried over sodium sulfate. Solvent was evaporated under reduced pressure and the residue crystallized from EtOH/water to give $1.15 \mathrm{~g}(91 \%)$ of compound $\mathbf{1}$ as a white solid, mp 71-73 ${ }^{\circ} \mathrm{C}$. IR/cm ${ }^{-1}$ (KBr): 3373, 1799, 1778, 1726, 1670, 1525, 1387, 1200, 719; ${ }^{1} \mathrm{H}$ NMR/ppm (DMSO, 600 MHz): 1.40 (s, Me), 1.66 (s, Me), 4.33 (d, $\left.\mathrm{CH}_{2}, J=5.9 \mathrm{~Hz}\right), 4.46$ (s, $\mathrm{C}_{2^{-}}$ $\mathrm{H}), 5.57$ (d, $\mathrm{C}_{5}-\mathrm{H}, J=4.0 \mathrm{~Hz}$ ), 5.73 (d, $\left.\mathrm{C}_{6}-\mathrm{H}, J=4.0 \mathrm{~Hz}\right), 7.26-7.36$ (m, Ph), 7.89-7.94 (m, 4HPhth), 8.78 (t, NH, $J=5.9 \mathrm{~Hz}$ ); ${ }^{13} \mathrm{C}$ NMR/ppm (DMSO, $150 \mathrm{MHz}$ ): 27.2 (q), 30.8 (q), 42.2 (t), 58.4 (d), 65.4 (s), 66.4 (d), 70.9 (d), 123.6 (d), 127.0 (d), 127.6 (d), 128.3 (d), 130.4 (s), 135.0 (d), 136.2 (s), 166.2 (s), 166.8 (s), 168.2 (s); HRMS (TOF, MS ES+)= 436.1348; requires 436.1331. Anal. Calcd for $\mathrm{C}_{23} \mathrm{H}_{21} \mathrm{~N}_{3} \mathrm{O}_{4} \mathrm{~S}: \mathrm{C}, 63.43 ; \mathrm{H}, 4.86$; N, 9.65; S, 7.36. Found: $\mathrm{C}, 63.27$; $\mathrm{H}$, 5.04; N, 9.46; S, 7.31 .

\section{2-((2S,5R,6R)-2-(Benzylcarbamoyl)-3,3-dimethyl-7-oxo-4-thia-1-aza-bicyclo[3.2.0]-heptane-} 6-yl-carbamoyl)benzoic acid (2). Compound 1 (3.0 g; $6.9 \mathrm{mmol})$ was dissolved in THF (60 $\mathrm{mL}$ ). The solution was cooled to $0{ }^{\circ} \mathrm{C}$ and sodium sulfide $(384 \mathrm{mg} ; 1.58 \mathrm{mmol})$ dissolved in water $(13 \mathrm{~mL})$ was added drop wise during $1 \mathrm{~h}$. The solution was acidified with $\mathrm{HCl}, 1.2 \mathrm{M}$ to pH 7 at $0{ }^{\circ} \mathrm{C}$. THF was evaporated and the residue washed with EtOAc $(30 \mathrm{~mL})$. Acetonitrile (3 $\mathrm{mL}$ ) was added to the water layer and the reaction mixture was acidified with $\mathrm{HCl}, 1.2 \mathrm{M}$ to $\mathrm{pH}$ 5 at $0{ }^{\circ} \mathrm{C}$. The precipitate was filtered and dried for 20 hours at $35{ }^{\circ} \mathrm{C} / 5 \mathrm{mbar}$ to obtain $1.48 \mathrm{~g}$ (46\%) of compound 2 as a white solid, mp 198-201 ${ }^{\circ} \mathrm{C}$. IR $/ \mathrm{cm}^{-1}(\mathrm{KBr}): 3400,3226,1804,1723$, 1710, 1658, 1623, 1530, 1248, 703; ${ }^{1} \mathrm{H}$ NMR (DMSO, $\left.600 \mathrm{MHz}\right): 1.39$ (s, Me), 1.57 (s, Me), $4.22\left(\mathrm{~s}, \mathrm{C}_{2}-\mathrm{H}\right), 4.31\left(\mathrm{~d}, \mathrm{CH}_{2}, J=5.9 \mathrm{~Hz}\right), 5.54\left(\mathrm{~d}, \mathrm{C}_{5}-\mathrm{H}, J=3.9 \mathrm{~Hz}\right), 5.55\left(\mathrm{dd}, \mathrm{C}_{6}-\mathrm{H}, J_{6-5}=4.1 ; J_{6-}\right.$ $\left.N_{H}=7.0 \mathrm{~Hz}\right), 7.24-7.35(\mathrm{~m}, \mathrm{Ph}), 7.40(\mathrm{dd}, 1 \mathrm{H}, \mathrm{Ft}, J=7.7 ; 1.0 \mathrm{~Hz}), 7.52(\mathrm{dt}, 1 \mathrm{H}, \mathrm{Ft}, J=7.6 ; 1.2$ $\mathrm{Hz}), 7.59$ (dt, 1H, Ft, $J=7.5 ; 1.2 \mathrm{~Hz}), 7.79$ (dd, 1H, Ft, $J=7.7 ; 1.0 \mathrm{~Hz}), 8.69$ (t, NH, J= 5.9 Hz), $9.28(\mathrm{~d}, \mathrm{NH}, J=7.0 \mathrm{~Hz}), 12.9(\mathrm{~s}, \mathrm{OH}) ;{ }^{13} \mathrm{C} \mathrm{NMR}$ (DMSO, $\left.150 \mathrm{MHz}\right): 26.5$ (q), 30.5 (q), 42.2 (t), 58.9 (d), 64.0 (s), 67.5 (d), 70.6 (d), 126.9 (d), 127.5 (d), 128.0 (d), 128.3 (d), 129.2 (d), 129.4 (d), 130.4 (s), 131.2 (d), 137.3 (s), 138.9 (s), 166.9 (s), 167.4 (s), 168.7 (s), 173.4; HRMS (TOF, 
MS ES+): 454.1420; requires 454.1437. Anal. Calcd for $\mathrm{C}_{23} \mathrm{H}_{23} \mathrm{~N}_{3} \mathrm{O}_{5} \mathrm{~S}: \mathrm{C}, 60.91 ; \mathrm{H}, 5.11 ; \mathrm{N}$, 9.27; S, 7.07. Found: C, 60.84; H, 5.21; N, 9.03; S, 6.90.

(Z)- $\mathrm{N}$-Benzyl-3,3-dimethyl-7-oxo-6-(3-oxoisobenzofurane-1(3H)-ylideneamino)-4-thia-1aza-bicyclo[3.2.0]heptane-2-carboxamide (3). Compound 2 (500 mg; $1.10 \mathrm{mmol}$ ) was dissolved in dioxane $(8.5 \mathrm{~mL})$ with addition of triethylamine $(0.15 \mathrm{~mL} ; 1.11 \mathrm{mmol})$. TFAA $(0.49$ $\mathrm{mL} ; 3.33 \mathrm{mmol}$ ) was added and the solution stirred at RT for $1 / 2 \mathrm{~h}$. The reaction mixture was added drop wise to the stirred ice/water mixture $(22 \mathrm{~g} / 40 \mathrm{~mL})$. The precipitate was filtered, washed with water and dried for $2 \mathrm{~h}$ at $35^{\circ} \mathrm{C} / 5 \mathrm{mbar}$ to obtain $475 \mathrm{mg}(95 \%)$ of compound 3 as a pale yellow solid, mp 130-133 ${ }^{\circ} \mathrm{C}$. IR $/ \mathrm{cm}^{-1}$ (KBr): 3367, 1801, 1706, 1672, 1534, 1270, 921, 703; ${ }^{1} \mathrm{H}$ NMR/ppm (DMSO, $\left.600 \mathrm{MHz}\right): 1.39$ (s, Me), 1.56 (s, Me), 4.27 (s, C $\left.2-\mathrm{H}\right), 4.32\left(\mathrm{~d}, \mathrm{CH}_{2}\right.$, $J=5.8 \mathrm{~Hz}), 5.67\left(\mathrm{~d}, \mathrm{C}_{5}-\mathrm{H}, J=4.2 \mathrm{~Hz}\right), 5.71\left(\mathrm{~d}, \mathrm{C}_{6}-\mathrm{H}, J=4.2 \mathrm{~Hz}\right), 7.25-7.35(\mathrm{~m}, \mathrm{Ph}), 7.90(\mathrm{dt}$, $1 \mathrm{H}$, Ft. $J=7.4, J=1.0 \mathrm{~Hz}), 7.96(\mathrm{dt}, 1 \mathrm{H}, \mathrm{Ft}, J=7.4, J=0.8 \mathrm{~Hz}), 8.00(\mathrm{~d}, 1 \mathrm{H}, \mathrm{Ft}, J=7.4 \mathrm{~Hz})$, 8.05 (d, 1H, Ft, $J=7.6 \mathrm{~Hz}$ ), 8.70 (t, NH, $J=5.9 \mathrm{~Hz}) ;{ }^{13} \mathrm{C}$ NMR (DMSO, $150 \mathrm{MHz}$ ): 26.5 (q), 30.5 (q), 42.2 (t), 64.0 (s), 66.9 (d), 67.5 (d), 70.6 (d), 123.2 (d), 125.6 (d), 127.0 (d), 127.5 (d), 128.3 (d), 130.4 (s), 134.0 (d), 135.0 (s), 136.2 (d), 138.9 (s), 150.6 (s), 163.6 (s), 166.9 (s), 173.4; HRMS (TOF, MS ES+): 436.1313; requires 436.1331. Anal. Calcd for $\mathrm{C}_{23} \mathrm{H}_{21} \mathrm{~N}_{3} \mathrm{O}_{4} \mathrm{~S}$ : C, 63.43; H, 4.86; N, 9.65; S, 7.36. Found: C, 63.29; H, 5.04; N, 9.43; S, 7.21.

\section{(2R,4S)- $N$-Benzyl-2-((1,3-dioxoisoindolin-2-yl)methyl)-5,5-dimethylthiazolidine-4-carbo-}

xamide hydrochloride (4). Mother liquor after filtration of compound $\mathbf{2}$ was left in an open flask at RT. The precipitate was filtered to give $85 \mathrm{mg} \mathrm{(3 \% )}$ of compound 4 as a white solid, $\mathrm{mp}$ $143-146{ }^{\circ} \mathrm{C}$. IR/ $\mathrm{cm}^{-1}$ (KBr): 3352, 1766, 1703, 1675, 1544, 1425, 1399, 1114, 1085, 712, 700; ${ }^{1} \mathrm{H}$ NMR (DMSO, $600 \mathrm{MHz}): 1.09$ (s, Me), 1.53 (s, Me), 3.35 (bs, $\mathrm{NH}_{2}{ }^{+}$), 3.47 (dd, $\mathrm{H}_{\mathrm{a}}-\mathrm{CH}_{2}, J=5.3$; $13.9 \mathrm{~Hz}), 3.61\left(\mathrm{~s}, \mathrm{C}_{4}-\mathrm{H}\right), 3.75$ (dd, $\left.\mathrm{H}_{\mathrm{b}}-\mathrm{CH}_{2}, J=9.8 ; 13.9 \mathrm{~Hz}\right), 4.30$ (dd, $\left.\mathrm{CH}_{2}, J=5.9 ; 15.0 \mathrm{~Hz}\right)$, $4.92\left(\mathrm{dd}, \mathrm{C}_{2}-\mathrm{H}, J=5.4 ; 9.7 \mathrm{~Hz}\right), 7.22-7.33$ (m, Ph), 7.84-7.89 (m, 4H-Phth), 8.61 (t, NH, $J=5.8$

$\mathrm{Hz}$ ); ${ }^{13} \mathrm{C}$ NMR (DMSO, $\left.150 \mathrm{MHz}\right): 27.7$ (q), 27.9 (q), 42.2 (t), 43.3 (t), 59.9 (s), 63.4 (d), 71.0 (d), 123.1 (d), 126.8 (d), 127.4 (d), 128.3 (d), 131.4 (s), 134.5 (d), 139.2 (s), 167.4 (s), 167.6 (s); HRMS (TOF, MS ES+): 410.1537; requires 410.1538.

\section{(2S,5R,6R)-6-Amino- $N$-benzyl-3,3-dimethyl-7-oxo-4-thia-1-aza-bicyclo[3.2.0]heptane-2-}

carboxamide (5). Compound 3 (920 mg; $2.11 \mathrm{mmol})$ was dissolved in DCM (50 mL) and cooled to $-75^{\circ} \mathrm{C}$ in acetone/dry ice bath. Solution of methyl hydrazine $(0.11 \mathrm{~mL} ; 2.13 \mathrm{mmol})$ in DCM $(2 \mathrm{~mL})$ was added drop wise and the reaction mixture was stirred for $1 / 2 \mathrm{~h}$ at $-75^{\circ} \mathrm{C}$. The cooling bath was removed and the reaction mixture stirred for $1 \mathrm{~h}$. The precipitate was formed at RT and filtered (compound 6). Mother liquor was extracted with $\mathrm{HCl}, 0.1 \mathrm{M}(2 \times 50 \mathrm{~mL})$. Water layer was washed with DCM $(10 \mathrm{~mL})$ and cooled to $0{ }^{\circ} \mathrm{C}$. Saturated solution of sodium hydrogen carbonate $(30 \mathrm{~mL})$ was added drop wise to $\mathrm{pH} 8.9$ and the reaction mixture extracted with DCM. Organic layer was dried on sodium sulfate and the solvent evaporated under reduced pressure to give $80 \mathrm{mg}(12 \%)$ of pale yellow foamy substance, $\mathrm{mp} 72-75^{\circ} \mathrm{C} . \mathrm{IR} / \mathrm{cm}^{-1}$ (KBr): 3302,1776 , 
1658, 1527, 1455, 1292, 700; $\left.{ }^{1} \mathrm{H} \mathrm{NMR/ppm} \mathrm{(DMSO,} 600 \mathrm{MHz}\right): 1.38$ (s, Me), 1.54 (s, Me), 4.11 $\left(\mathrm{s}, \mathrm{C}_{2}-\mathrm{H}\right), 4.28$ (d, $\left.\mathrm{CH}_{2}, J=6.0 \mathrm{~Hz}\right), 4.52\left(\mathrm{~d}, \mathrm{C}_{5}-\mathrm{H}, J=4.3 \mathrm{~Hz}\right), 5.41$ (d, $\left.\mathrm{C}_{6}-\mathrm{H}, J=4.3 \mathrm{~Hz}\right), 7.23-$ 7.33 (m, Ph), 8.62 (t, NH, J=5.8 Hz); ${ }^{13} \mathrm{C}$ NMR (DMSO, $\left.150 \mathrm{MHz}\right): 26.5$ (q), 30.6 (q), 42.1 (t), 62.4 (d), 63.2 (s), 69.8 (d), 70.4 (d), 126.9 (d), 127.5 (d), 128.3 (d), 138.9 (s), 167.2 (s), 179.3; HRMS (TOF, MS ES-): 304.1112; requires 304.1120.

(2R,4S)-N-Benzyl-2-(1-(1,3-dioxoisoindolin-2-yl)-2-hydrazinyl-2-oxoethyl)-5,5-dimethylthiazolidine-4-carboxamide (9). Compound 7 (180 mg, $0.36 \mathrm{mmol})$ was suspended in 2-PrOH $(4 \mathrm{~mL})$ and stirred for $20 \mathrm{~h}$ at $80{ }^{\circ} \mathrm{C}$. The reaction mixture was filtered and the mother liquor was evaporated under reduced pressure. The residue was purified on silica gel in a system DCM:MeOH: $\mathrm{NH}_{4} \mathrm{OH}=4: 1: 0.1$ to obtain $76 \mathrm{mg}(45 \%)$ of white foamy solid, $\mathrm{mp} 100-103{ }^{\circ} \mathrm{C}$. $\mathrm{IR} / \mathrm{cm}^{-1}$ (KBr): 3322, 1776, 1716, 1661, 1539, 1455, 1386, 1336, 717, 701; ${ }^{1} \mathrm{H} \mathrm{NMR} / \mathrm{ppm}$ (DMSO, $600 \mathrm{MHz}$ ): 1.04 (s, Me), 1.46 (s, Me), 3.41 (d, $\mathrm{C}_{4}-\mathrm{H}, J=13.3 \mathrm{~Hz}$ ), 3.84 (dd, $\mathrm{NH}_{\text {thiazol., }}$ $J=8.1,13.3 \mathrm{~Hz}), 4.18$ (bs, $\left.\mathrm{NH}_{2}\right), 4.22\left(\mathrm{dd}, \mathrm{CH}_{2}, J=6.0,15.1 \mathrm{~Hz}\right), 4.66$ (d, $\left.\mathrm{C}_{1},-\mathrm{H}, J=10.3 \mathrm{~Hz}\right)$, 5.08 (dd, $\mathrm{C}_{2}-\mathrm{H}, J=8.2,10.2 \mathrm{~Hz}$ ), 7.16-7.28 (m, Ph), 7.86-7.90 (m, 4H-Phth), 8.46 (t, NH, J=6.0 $\mathrm{Hz}$ ), 9.32 (s, NH $\mathrm{NH}_{\text {hdrazide }}$ ); ${ }^{13} \mathrm{C} \mathrm{NMR} / \mathrm{ppm}$ (DMSO, $150 \mathrm{MHz}$ ): 27.2 (q), 27.4 (q), 41.9 (t), 56.3 (d), 57.7 (s), 63.1 (d), 71.7 (d), 123.1 (d), 126.7 (d), 127.1 (d), 128.2 (d), 131.8 (s), 134.4 (d), 139.2 (s), 166.5 (s), 167.0 (s), 167.3; HRMS (TOF, MS ES+): 468.1716; requires 468.1706.

\section{(2R,4S)-N-Benzyl-2-(1-(2-(hydrazinecarbonyl)benzamido)-2-hydrazinyl-2-oxoethyl)-5,5-}

dimethylthiazolidine-4-carboxamide (10). Compound 1 (0.50 g, $1.15 \mathrm{mmol})$ was dissolved in toluene $(10 \mathrm{~mL})$ and hydrazine $1.0 \mathrm{M}$ in THF $(5 \mathrm{~mL}, 5.00 \mathrm{mmol})$ was added. The reaction mixture was heated to $80{ }^{\circ} \mathrm{C}$ and stirred for 10 minutes, cooled to $0{ }^{\circ} \mathrm{C}$ and stirred for 10 minutes. The precipitate was filtered, washed with water $(12 \mathrm{~mL})$ and dried at $35{ }^{\circ} \mathrm{C} / 5 \mathrm{mbar}$ for $20 \mathrm{~h}$. Dried product was stirred in EtOH (3 mL) for $20 \mathrm{~h}$ and filtered to give $138 \mathrm{mg}(24 \%)$ of white solid, mp 141-144 ${ }^{\circ} \mathrm{C}$. IR/cm ${ }^{-1}(\mathrm{KBr}): 3305,1793,1726,1638,1650,1540,1455,1330$, 700; ${ }^{1} \mathrm{H} \mathrm{NMR} / \mathrm{ppm}$ (DMSO, $\left.600 \mathrm{MHz}\right): 1.15$ (s, Me), 1.52 (s, Me), 3.55 (d, C $4-\mathrm{H}, J=11.4 \mathrm{~Hz}$ ), 3.91 (dd, $\left.\mathrm{NH}_{\text {thiazol. }}, J=7.6,11.3 \mathrm{~Hz}\right), 4.27$ (bs, $\left.\mathrm{NH}_{2}\right), 4.30$ (dd, $\left.\mathrm{CH}_{2}, J=6.0,15.0 \mathrm{~Hz}\right), 4.40$ (bs, $\mathrm{NH}_{2}$ ), 4.50 (t, $\left.\mathrm{C}_{1},-\mathrm{H}, J=8.3 \mathrm{~Hz}\right), 4.94$ (t, $\left.\mathrm{C}_{2}-\mathrm{H}, J=7.7 \mathrm{~Hz}\right), 7.21-7.31(\mathrm{~m}, \mathrm{Ph}), 7.45-7.50$ (m, 4HPhth), 8.38 (d, NH, $J=8.8 \mathrm{~Hz}), 8.45$ (t, NH, $J=6.0 \mathrm{~Hz}), 9.21$ (s, $\mathrm{NH}_{\text {hydrazide }}$ ), 9.59 (s, $\mathrm{NH}_{\text {hydrazide }}$ ); ${ }^{13} \mathrm{C} \mathrm{NMR} /$ ppm (DMSO, $150 \mathrm{MHz}$ ): 27.6 (q), 28.2 (q), 42.5 (t), 56.8 (d), 58.6 (s), 66.4 (d), 72.6 (d), 127.2 (d), 127.8 (d), 128.0 (d), 128.3 (d), 128.6 (d), 129.8 (d), 130.1 (d), 134.3 (s), 136.4 (s), 139.7 (s), 168.0 (s), 168.2 (s), 168.6 (s), 168.9 (s); HRMS (TOF, MS ES+): 500.2063; requires 500.2080; $\mathrm{KF}_{\mathrm{Q}}\left(\mathrm{H}_{2} \mathrm{O}\right): 1.80 \%$ (hemihydrate: 1.78\%). Anal. Calcd for $\mathrm{C}_{46} \mathrm{H}_{60} \mathrm{~N}_{14} \mathrm{O}_{9} \mathrm{~S}_{2} \cdot 1 / 2 \mathrm{H}_{2} \mathrm{O}$ : $\mathrm{C}$, 54.32; H, 5.95; N, 19.28; S, 6.30. Found: C, 54.15; H, 6.17; N, 19.08; S, 6.53.

\section{(2R,4S)-2-(1-Amino-2-hydrazinyl-2-oxoethyl)- $N$-benzyl-5,5-dimethylthiazolidine-4-carbo-} xamide (11). Compound 1 (1.0 g, $2.3 \mathrm{mmol})$ was dissolved in EtOH (50 mL) and hydrazine monohydrate $(0.5 \mathrm{~mL}, 10 \mathrm{mmol})$ was added. The reaction mixture was stirred for $1 \mathrm{~h}$ at reflux and cooled to RT. The precipitate was filtered and mother liquor was evaporated under reduced 
pressure. The residue after evaporation was purified on silica gel in a system DCM:MeOH: $\mathrm{NH}_{4} \mathrm{OH}=4: 1: 0.1$ to obtain $280 \mathrm{mg}$ (36\%) of yellow foamy substance, mp 65-68 ${ }^{\circ} \mathrm{C} . \mathrm{IR} / \mathrm{cm}^{-1}$ (KBr): 3294, 1659 (broad), 1548, 1454, 1132, 1032, 736, 700; ${ }^{1} \mathrm{H} \mathrm{NMR} / \mathrm{ppm}$ (DMSO, $600 \mathrm{MHz}$ ): 1.12 (s, 3H), 1.47 (s, 3H), 2.20 (bs, $\mathrm{NH}_{2}$ ), 3.03 (d, $\mathrm{C}_{1}$,-H, J=8.4 Hz), 3.39 (d, $\left.\mathrm{C}_{4}-\mathrm{H}, J=12.4 \mathrm{~Hz}\right), 3.96\left(\mathrm{dd}, \mathrm{NH}_{\text {thiazol. }} J=8.0,12.4 \mathrm{~Hz}\right), 4.20\left(\mathrm{bs}, \mathrm{NH}_{2}\right), 4.31\left(\mathrm{dd}, \mathrm{CH}_{2}\right.$, $J=6.0,14.9 \mathrm{~Hz}), 4.58\left(\mathrm{t}, \mathrm{C}_{2}-\mathrm{H}, J=8.0 \mathrm{~Hz}\right), 7.23-7.34(\mathrm{~m}, \mathrm{Ph}), 8.51$ (t, NH, $\left.J=5.9 \mathrm{~Hz}\right), 9.10$ (s, $\left.\mathrm{NH}_{\text {hydrazide }}\right) ;{ }^{13} \mathrm{C}$ NMR/ppm (DMSO, $\left.75 \mathrm{MHz}\right): 27.9$ (q); 28.0 (q); 42.6 (t); 59.1 (s); 59.9 (d); 69.7 (d); 72.3 (d); 127.3 (d); 127.9 (d); 128.8 (d); 139.7 (s); 168.3 (s); 171.5 (s); HRMS (TOF, MS $\mathrm{ES}+)$ : 338.1633; requires 338.1651.

\section{References}

1. (a) Grafe, U. Biochemie Der Antibiotika; Spektrum Akademischer Verlag: Heidelberg, 1992, p359. (b) Jones, R. N.; Barry, A. L.; Thornsberry, C. J. Antimicrob. Chemother. 1989, 24(A), 9.

2. Chu, D. T.; Plattner, J.; Katz, L. J. Med. Chem. 1996, 39, 3853.

3. Page, M. I. The Chemistry of $\beta$-Lactams; Blackie Academic \& Professional: London 1992.

4. (a) Ramsay, B. G.; Stoodley, R. J. J. Chem. Soc. 1969, C, 1319. (b) Boissannas, R. A. Adv. Org. Chem. 1963, 3, 179.

5. Ing, H. R.; Manske, R. H. F. J. Chem. Soc. 1926, 2348.

6. (a) Khalil, N. S. A. M. Nucleosides, Nucleotides \& Nucleic Acids 2005, 24(9), 1277. (b) Jarrahpour, A. A.; Shekarriz, M.; Taslimi, A. Molecules 2004, 9(1 and 2), 29. (c) Del Buttero, P.; Molteni, G.; Papagni, A. Tetrahedron: Asymmetry 2003, 14, 3949.

7. Fekner, T.; Baldwin, J. E.; Adlington, R. M.; Jones, T. W.; Prout, C. K.; Schofield, C. J. Tetrahedron 2000, 56, 6053.

8. Misner, J. W.; Fisher, J. W.; Gardner, J. P.; Pedersen, S. W.; Trinkle, K. L.; Jackson, B. G.; Zhang, T. Y. Tetrahedron Lett. 2003, 44, 5991.

9. Aszodi, J.; Bonnet, A.; Teutsch, G. Tetrahedron 1990, 46, 1579.

10. Del Buttero, P.; Molteni, G.; Papagni, A.; Miozzo, L. Gazz. Chim. Ital. 2004, 15(16), 2555.

11. (a) Kukolja, S.; Lammert, S. R. J. Am. Chem. Soc. 1975, 97, 5582. (b) Kukolja, S.; Lammert, S. R.; Ellis, A. I. Croat. Chem. Acta 1977, 49, 779.

12. (a) Cerić, H.; Kovačević M.; Šindler-Kulyk, M. Tetrahedron 2000, 56, 3985. (b) Cerić, H.; Kovačević M.; Šindler-Kulyk, M. Twelfth European Symposium on Organic Chemistry, Groningen, The Netherlands, July 13-18, 2001: Abstract No. P1-185.

13. Perron, Y. G.; Minor, W. F.; Crast, L. B.; Gourevitch, A.; Lein, J.; Cheney, L. C. J. Med. Chem. 1962, 5, 1016.

14. Baldwin, J. E.; Chan, R. Y.; Sutherland, J. D. Tetrahedron Lett. 1994, 35, 5519.

15. Prasada Rao, K. V. V.; Dandala, R.; Handa, V. K.; Subramnyeswara Rao, I. V.; Rani, A.; Naidu, A. ARKIVOC 2006, (xv), 61. 